\title{
住民主体の地域づくりにおける連続ワークショップのあり方 一繁本県合志町すすかかけ台地区魅力化計画策定を事例としてー
}

藤芳隆也, 後藤春彦, 赤尾光司, 飯島克如, 杉友 壮, 前川裕介, 村上佳代 248

\begin{abstract}
高野公男 [東北芸術工科大学 工博] 近年, 住民の地域づくりへの主体的なかかわりが重視され，ワー クショップがその有力な手法として各地で試みられるようになっ た。しかしその手法の有効性に関して, 断片的な報告はみられるも のの, 取り組みの全過程を通して検証する体系だった報告は少な かった。本稿は, 手法活用の全体像を示し, そのプロセスと成果を 詳細に報告している。「ワークショップの目標とプログラム (図 1)」 では, 時間的制約の中でのプログラムの組みたて方に特色がみられ, 4 回のワークショップの内容が臨場感を伴うように再現されてい る。「連続ワークショップの成果物 (図 2)」からは, 住民の漠然とし た理想・問題認識の段階から具体的な課題を抽出する過程で, W.S の学習効果や主体的参加への意識の変化が伺える。住民が提示した 施策を見ると, すずかけ台は, 緩やかな高㱓化が進む落ちついた町 のようだが，何よりも町の人々が身の丈にあった魅力づくりに取り 組む姿に共感がもてた。このイベントにより地域社会に小さなさざ 波が生じていることは間違いない。本稿はこの領域の技術報告とし てもまとまっており，類似ケースの参考になると考えられる。数年 後の事業評価にも期待したい。
\end{abstract}

木下 勇 [千葉大学園芸学部 助教授] まだ絶対量は少ないとはいえ，住民参加ないし住民主体のまちづ くクのワークショップの実践が各地で行われるようになってきた。 その中でも県行政が後押しをして取り組んでいるのが熊本県であ る。本報告はそういう中でも精力的に取り組んだ事例といえる。ワー クショップを開催するにも参加者の人集めに苦労する今日，このよ うに人々が楽しみながら参加できる方法，しかも高跘化など媣刻な 課題が山積みとなっていても, 楽しい場面の展開でその課題に向け た住民の立ち上がりがうまれてくる過程を緅った本報告はおおいに 参考となる。欲を言之ば参加者の集めかたにも言及があるとよかっ た。初回に 160 人の参加とは驚きでもある。また主体形成の点からは 参加者の反応など意識の変化も知りたいところである。これまで数 人の識者からワークショップが住民参加のアリバイ工作のように扱 われる危険性の問題も提起されている。最終成果で住民が主体的に 行うとしてあげられた計画項目がその後どのよjに実施されたか, 事後をみることからワークショップの真の成果が判断できるであろ う。ぜひとも続編を期待したい。
中川 理 [京都工芸繊維大学 助教授・工博 $]$ 国際観光委員会の議事録に基づいて, 上高地の観光地としての開 発過程を追ったもので, 戦前の, 官民共同による観光地開発の構図 を明らかにしたという点において高く評価できるものである。しか し, 肝心の同委員会の設置理由やその背景, あるいは設置過程など について詳細が明らかにされていないのが惜しまれる。報告では委 貝会のメンバーの発言の分析が行われているが，例之ば，なぜその 人たちが選ばれたのか，その理由については言及されていない。全 体に事業の経過報告にとどまっており, 観光地開発に果たした委員 会の役割や位置づけについて明らかにできていない。

観光に関する研究は, 政策・経営論, 地理学, 社会学, 民俗学な ど様々な分野から可能である。逆に言えば, 観光それ自身だけで成 立する研究はありえないはずだ。その意味で，同委員会の位置づけ は，政策史に繁がる重要な意味を持つものだろうし，あるいは大倉 委員と藤村委員の開発に対する考之方の落差の中に, 観光という概 念の摇れを読み込む視点もありえるのではないか。いずれにしても， 論文報告集などの他の場所で，さらに踏み込んだ議論が行われるこ とを期待したい。
藤原恵洋 [九州芸術工科大学芸術工学部芸術情報設計学科 助教授・工博] 明治以降，外国人がもたらしたものは舶来文明や西欧の生活様式 だけではない。国内に滞在すれば宿泊, 飲食, 移動と経費がかかる。 さらにはモースのように，異文化記念の土産にも贅を尽くせば，莫 大な外貨が落ちる。そこから国際観光が発展し, 昭和初期の外貨獲 得高は輸出品目の生系, 綿織物に次ぐ力を得ていた。本研究の背景 もここにあり，20３0 年代の観光地・上高地の形成過程を国際観光 の動きに関係づけたものである。さらに国際観光に関する建築的課 題の解明へも波及するものとなっている。

本研究の知見は, (1)都市の電力需要が電源開発に伴う国内の渓谷 地の開発に強い影響を与之た結果, 上高地の初期開発が可能となっ た。(2) 1930 年に設置された政府機関国際観光委員会は, 当時悪化し た対外貿易収支を改善する目的で国際観光地の整備を急いだが，上 高地の国際観光地化もこうした動きの中で進められた。(3)景勝地の 保護の観点を凌駕しながら開発が進展, 帝国ホテル大倉喜七郎の主 導の下で新設ホテルとアクセス道路の建設が行われた, の 3 点に代 表される。これらは各々, 都市化, 国際化, 観光観の近代化の視点 で実証されており，学際的な研究であると評価することができる。
堀 勇良 [文化庁建造物課 工博] 『日本近代建築総覧』（1980 年韓国・台湾を含む）以降，かつて 日本統治下にあった地域の建築活動に関する調查研究は飛躍的に進 捗しており，本調查報告もこの延長にあるとしてよいが，いまだく統 治〉の比較研究に至っているとは言い難い。「調查結果の概要」に「木 造あるいは組積造のものはほとんど失われ」とあるが，他の旧日本 統治地域の残存状況とは样相が異なるようである。また，「ユジ， 一一ハリンスク市街地と建築遺構」に「終戦直後の市街地改造」と あるが，他のところでは統治下における市街地改造が一般的で「終 戦直後の市街地改造」はあまり聞かない。かように，「南サハリンに おける日本統治期建築の現存状況」調查は統治下建築活動の調查の みならず，〈統治〉の比較研究を要請しているように思われる。旧樺 太宁営縉の組織および活動，民間建築事務所や施工業者の動向につ いての調査研究はもとよりとして，そのう之にたっての統治比較研 究の進展に期待したい。
西澤泰彦 [名古屋大学大学院工学研究科 助教授・博士 (工学)] 本報告は, サハリンの近代建築史研究として, また日本近代建築 史研究として重要な意味を持つ報告である。建築史研究における現 存状況の把握に対して, 建築史から風俗史一の転換として歴史的視 点の喪失につながることを危惧する声もあるが, 東アジア地域の 19 世紀後半から 20 世紀にかけての建築を対象とした研究では建築の 基本的デ一夕を収集する上で必要不可欠な作業である。

『日本近代建築総覧』には韓国と台湾における日本支配時期の建築 が収録されているが, 日本支配地であった他のアジア地域における 同時代の建築は収録されていない。南サハリンは植民地ではないが， 日露戦争によって主権を回復し, 日本の敗戦によって日本が主権を 失った地域である。日本近代建築を絵体として把握するには，この ような戦前の植民地など, 実際に日本人が生活していた地域の建築 を無視できないはずである。

今後, 著者に望むことは, 資料収集を進め, 建築年, 設計者, 施 工者など各々の建築の基本的情報を確定し, 南サハリン日本統治時 代建築の総体を把握することである。 